\begin{tabular}{|c|c|c|c|}
\hline $\begin{array}{l}\text { Case Reports in } \\
\text { Dematoloy }\end{array}$ & $\begin{array}{l}\text { Case Rep Dermatol 2010;2:165-168 } \\
\text { DOI: 10.1159/000320476 }\end{array}$ & $\begin{array}{l}\text { Published online: } \\
\text { September 1, } 2010\end{array}$ & $\begin{array}{l}\text { () } 2010 \text { S. Karger AG, Basel } \\
\text { ISSN } 1662-6567 \\
\text { www.karger.com/cde }\end{array}$ \\
\hline
\end{tabular}

\title{
Plaque-Like Sclerodermiform Localized Mucinosis Rapidly Responsive to Topical Tacrolimus
}

\author{
R. Schmaltz T. Vogt C.S.L. Müller \\ Department for Dermatology, Saarland University Hospital, Homburg/Saar, \\ Germany
}

\section{Key Words}

Lichen myxedematosus · Mucinosis · Mucin · Scleromyxedema

\begin{abstract}
We report the successful treatment of plaque-like sclerodermiform mucinosis using tacrolimus ointment topically. We present a 70 -year-old male with a large chronic erythema and hardening of the nuchal skin and shoulder area. Subjective symptoms were a moderate pruritus and a rather disabling stiffness. A biopsy specimen revealed typical features of lichen myxedematosus. In a subsequent clinical examination, no associated illnesses such as hypothyroidism or gammopathy were found. Since no established therapy exists for this condition, and as there was a lack of response to potent topical glucocorticosteroids, tacrolimus $0.03 \%$ ointment was used off-label twice daily. Surprisingly, this resulted in a rapid, almost complete clearance of the skin within three weeks of treatment.
\end{abstract}

\section{Case Report}

A 70-year-old male patient presented with a 2-month history of an extensive erythematous plaque, dermo-epidermal thickening, and progressive scleroderma-like hardening of the skin on the neck and shoulder area. A close-up view showed small, merging, lichenoid papules (fig. 1).

The medical history was negative for other skin diseases. The subjective symptoms were a moderate pruritus and a rather disabling progressive stiffness of the nuchal area as well as of the shoulder area. No topical therapy had been applied yet. Co-existing medical conditions included spino-bulbar muscle dystrophia (type Kennedy), diabetes mellitus and a resected carcinoma of the urinary bladder.

A laboratory work-up including complete blood cell count and comprehensive screening for viral hepatitis, Borrelia serology as well as erythrocyte sedimentation rate, C-reactive protein, hemostaseology and urine analysis were normal. Increased thyroid autoantibodies were present (thyroglobulin-antibodies, $469 \mathrm{IU} / \mathrm{ml}$; thyroperoxidase antibodies, $192 \mathrm{IU} / \mathrm{ml}$ ); however, peripheral 


\begin{tabular}{c|l|l|l}
$\begin{array}{c}\text { Case Reports in } \\
\text { Demlintoloyy }\end{array}$ & $\begin{array}{l}\text { Case Rep Dermatol 2010;2:165-168 } \\
\text { DOI: } 10.1159 / 000320476\end{array}$ & $\begin{array}{l}\text { Published online: } \\
\text { September 1, 2010 }\end{array}$ & $\begin{array}{l}\text { O 2010 S. Karger AG, Basel } \\
\text { ISSN 1662-6567 } \\
\text { www.karger.com/cde }\end{array}$ \\
\hline
\end{tabular}

thyroid hormones were normal. Paraproteins were detected neither in the serum nor in the urine by electrophoresis and immunofixation, respectively.

A 6-mm punch biopsy from the left upper back was obtained for histopathologic analysis. Hematoxylin-eosin staining showed a partial loss of rete ridges in an otherwise normal epidermis. Basal keratinocytes were strongly pigmented, and stained positive with Fontana-Masson melanin stain. The dermis showed a subtle superficial perivascular inflammatory lymphocytic infiltrate and prominent perifollicular and interstitial deposition of mucin without a substantial increase of interstitial fibroblasts. The mucin was highlighted with colloidal iron staining (fig. 2). The patient received treatment with topical steroids ( $0.1 \%$ mometasone) for 8 weeks which yielded neither a subjective nor an objective improvement of the skin lesions. Hence, topical treatment was changed to $0.03 \%$ tacrolimus (Protopic ${ }^{\circledR}$ ) twice daily, resulting in a nearly complete reduction of hardening and erythema of the previously affected skin within three weeks. Due to the good clinical response to this therapy, no vehicle control was performed.

\section{Discussion}

Cutaneous mucinoses comprise different entities with diffuse or focal deposition of mucin. Mucin consists of a mixture of glycosaminoglycans (hyaluronic acid/dermatan sulfate) either unbound (e.g. hyaluronic acid) or protein-bound (e.g. proteoglycan). Most glycosaminoglycans are generated by fibroblasts and/or keratinocytes.

In 1969, Montgomery and Underwood [1] first made a distinction between lichen myxedematosus (LM), scleromyxedema, and generalized myxedema by means of different clinical patterns.

More recently, according to different etiologies, pathogenesis and skin distribution, a classification has been set up by Rongioletti and Rebora differentiating three major categories: (a) generalized mucinosis (scleromyxedema), (b) localized and (c) atypical forms [2]. The localized variants comprise five subtypes including discrete papular LM, acral persistent papular mucinosis, juvenile and adult variant of self-healing papular mucinosis, papular mucinosis of the infancy and nodular LM $[3,4,2,5]$. As the morphology of the case reported herein does not fit well into the localized variants as described, we would assign our observation to the third group of the atypical forms of mucinoses. More typical localized variants present with skin-colored to reddish, firm papules or nodules on the upper extremities, trunk, thigh and sometimes on acral skin. Clinical differentials of LM include granuloma annulare, all other kinds of lichen (ruber, amyloidosus, etc.), reticulate erythematous mucinosis (REM) syndrome and, if diffuse, scleredema of Buschke.

Histopathologically, the hallmarks of localized mucinosis are deposition of mucin with a varying degree of proliferating fibroblasts and a whirly arrangement of collagen bundles in late stages of the disease. Perivascular lymphocytic infiltrates can be observed.

The histologic differentials in case of discrete or marginal fibroblast proliferation include myxedema and scleredema. Therefore, the diagnosis requires an analysis of the clinical picture and associated illnesses. As a rule, localized papular mucinoses are only exceptionally associated with hepatitis C, HIV/AIDS, monoclonal gammopathy, or plasmocytoma.

To date, no guidelines for the treatment of localized mucinoses exist. Usually, topical steroids are used as first-line therapy. Circumscribed surgery, dermabrasion or laser therapy (carbon dioxide laser) can also be considered. In generalized forms, application of 


\begin{tabular}{c|l|l|l}
$\begin{array}{c}\text { Case Reports in } \\
\text { Demlintoloyy }\end{array}$ & $\begin{array}{l}\text { Case Rep Dermatol 2010;2:165-168 } \\
\text { DOI: } 10.1159 / 000320476\end{array}$ & $\begin{array}{l}\text { Published online: } \\
\text { September 1, 2010 }\end{array}$ & $\begin{array}{l}\text { O 2010 S. Karger AG, Basel } \\
\text { ISSN 1662-6567 } \\
\text { www.karger.com/cde }\end{array}$ \\
\hline
\end{tabular}

systemic steroids, chlorambucil, cyclophosphamide, aromatic retinoids, or chloroquine has been reported [6].

Topical tacrolimus or pimecrolimus have been reported as useful in rather discrete variants $[6,7,8]$. Transforming growth factor-beta and tumor necrosis factor-alpha are thought to play a major role in the pathogenesis of localized mucinosis [7]. Thus, positive local effect of topical tacrolimus is probably due to its immunosuppressive effects (blocking calcineurin signal pathway, inhibiting tumor necrosis factor-alpha secretion in human keratinocytes and inhibiting collagen synthesis) [7].

With the patient presented here we want to report another case of rapid improvement of an atypical plaque-like sclerodermiform mucinosis that caused considerable impairment of the patient's quality of life due to skin hardening of the nuchal area, and we want to expand the possible applications of topical tacrolimus in dermatology.

\section{Conflict of Interest}

The authors disclose no commercial or similar relationships to products or companies mentioned in or related to the subject matter of the article submitted.
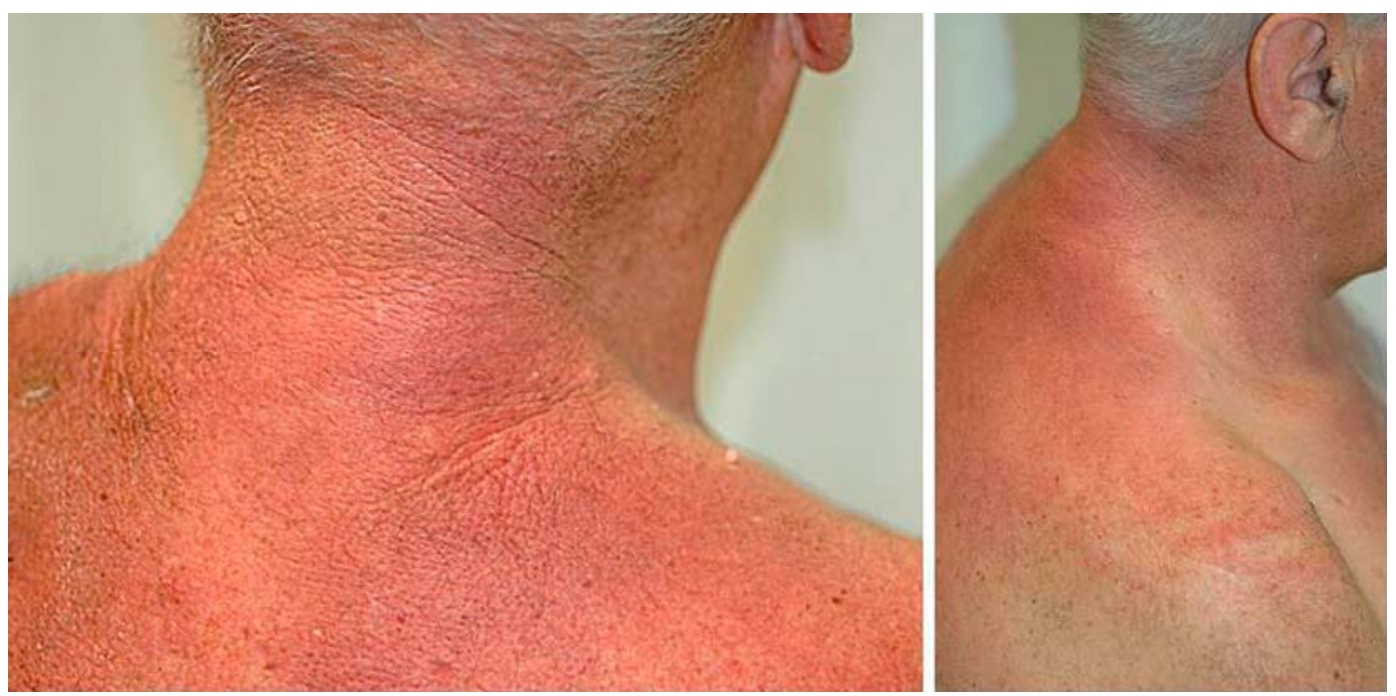

Fig. 1. Extensive sclerodermiform plaque of the neck and shoulder area. 


\begin{tabular}{l|l|l|l}
$\begin{array}{c}\text { Case Reports in } \\
\text { Dermatoloyy }\end{array}$ & $\begin{array}{l}\text { Case Rep Dermatol 2010;2:165-168 } \\
\text { DOI: } 10.1159 / 000320476\end{array}$ & $\begin{array}{l}\text { Published online: } \\
\text { September 1, 2010 }\end{array}$ & $\begin{array}{l}\text { O 2010 S. Karger AG, Basel } \\
\text { ISSN 1662-6567 } \\
\text { www.karger.com/cde }\end{array}$ \\
\hline
\end{tabular}
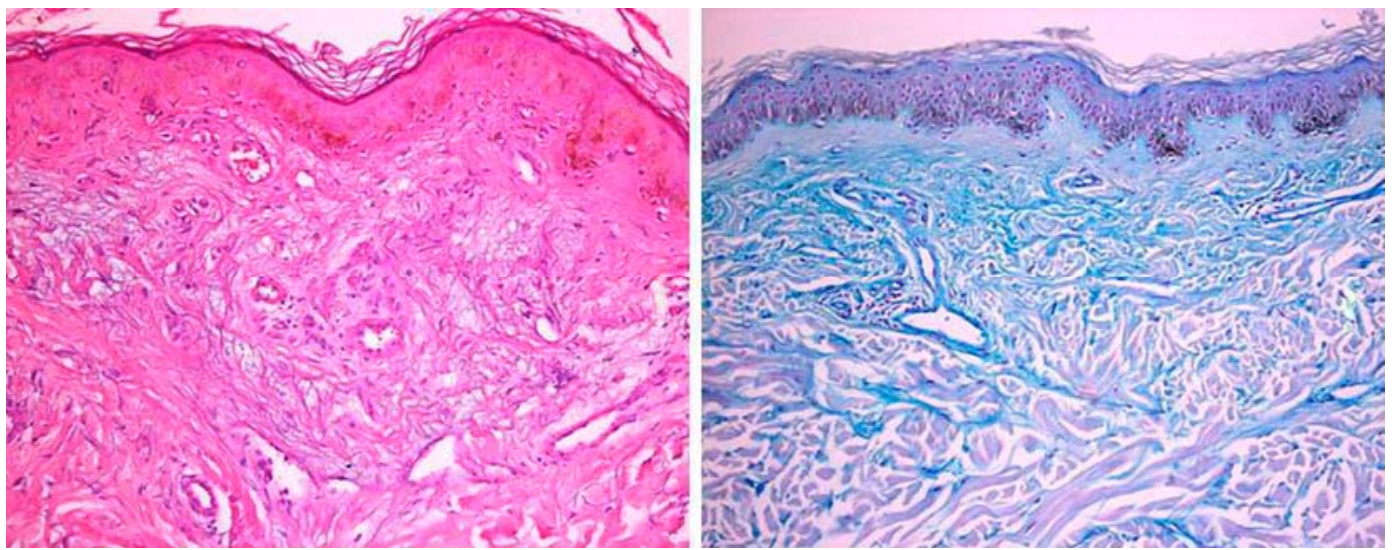

Fig. 2. Left: Hematoxylin and eosin-stained slide, $\times 200$. Superficial dermal perivascular inflammatory lymphocytic infiltrate. Striking perifollicular and interstitial deposition of mucin without substantial increase of interstitial fibroblasts. Right: Colloidal iron-stained slide, $\times 200$. Deposition of interstitial mucin.

\section{References}

1 Montgomery H, Underwood LJ: Lichen myxedematosus; differentiation from cutaneous myxedemas or mucoid states. J Invest Dermatol 1953;20:213-236.

2 Rongioletti F, Rebora A: Updated classification of papular mucinosis, lichen myxedematosus, and scleromyxedema. J Am Acad Dermatol 2001;44:273-281.

-3 Aydingöz IE, Candan I, Dervent B: Self-healing juvenile cutaneous mucinosis. Dermatology 1999;199:57-59.

4 Lum D: Cutaneous mucinosis of infancy. Arch Dermatol 1980;116:198-200.

5 Rongioletti F, Rebora A, Crovato F: Acral persistent papular mucinosis: a new entity. Arch Dermatol 1986;122:1237-1239.

6 Rongioletti F: Lichen myxedematosus (papular mucinosis): new concepts and perspectives for an old disease. Semin Cutan Med Surg 2006;25:100-104.

7 Rongioletti F, Zaccaria E, Cozzani E, et al: Treatment of localized lichen myxedematosus of discrete type with tacrolimus ointment. J Am Acad Dermatol 2008;58:530-532.

-8 Sulit DJ, Harford R, O’Neill JT: Discrete papular form of lichen myxedematosus: a case report and review of the literature. Cutis 2005;75:105-112. 